\title{
Isolation of Food-Borne Microorganisms from Atlantic Mackerel and Disinfection of the Raw Fish by Radiation, Low Temperature and Combination Treatments
}

\author{
Manik Hossain ${ }^{1}$, M Kamruzzam Munshi², Rasheda Yasmin Shilpi ${ }^{1}$ and Harun-Or-Rashid ${ }^{2 *}$ \\ ${ }^{1}$ Department of Botany, Jahangirnagar University, Savar, Dhaka 1342, Bangladesh, ${ }^{2}$ Microbiology \& Industrial Irradiation Division, Institute of \\ Food \& Radiation Biology, Atomic Energy Research Establishment, Ganakbari, Savar, Dhaka 1000, Bangladesh
}

[Received 22 October 2008; Accepted 07 November, 2009]

\begin{abstract}
An investigation was undertaken for the isolation and identification of fish-borne microorganisms from mackerel fish (Scomberomorus guttatus) collected from Savar Bazar. Radiation, low temperature $\left(-20^{\circ} \mathrm{C}\right)$ and combination treatments were then applied for the decontamination of associated organisms. The ranges of total viable bacterial count, total coliform count, total faecal coliform count and total staphylococcal count varied from $6.5 \times 10^{4}$ to $1.04 \times 10^{5}, 2 \times 10^{2}$ to $4.0 \times 10^{2}$, 0 to $1 \times 10^{2}$ and $4.4 \times 10^{4}$ to $3.8 \times 10^{4} \mathrm{cfu} / \mathrm{g}$ respectively, while the total fungal count was nil. Sixty-four bacterial isolates were identified including Staphylococcus (19\%), Micrococcus (11\%), Enterobacter (8\%), Klebsiella (17\%), Bacillus (19\%), Escherichia (17\%) and Pseudomonas (9\%). To disinfect the microorganisms, the samples were irradiated at different doses (0-10.0 kGy) of gamma irradiation. Total coliform and total faecal coliform bacteria were inactivated below the detectable level at 2.5 kGy of irradiation. The number of total viable bacteria decreased by three logs when irradiated at $5.0 \mathrm{kGy}$ and the number of Staphylococcus bacteria were eliminated completely after the irradiation dose of $5.0 \mathrm{kGy}$. During frozen storage, the total viable bacterial counts were gradually declined in all the samples. After six months of storage the bacterial counts were decreased about one log in all of the samples. It has been observed that combination treatments (irradiation and freezing) are more effective than the single treatment for eliminating the fish-borne bacteria.
\end{abstract}

Keywords: Mackerel fish, Microbial contamination, Irradiation, Low temperature

\section{Introduction}

Fish is a good source of protein and minerals such as calcium, phosphorous and iron, trace elements like iodine (in marine fishes), as well as vitamins $A$ and $\mathrm{D}^{1}$. The high content of polyunsaturated fatty acids requirement probably helps lower cholesterol levels. Thus, from nutritional point of view, fish is important in the diet of the developing world ${ }^{2}$. Though fish is highly nutritious and tasty, it is very perishable and cannot be kept for long times for consumption. Thus, in question of preservation, spoilage of fish has drawn the attention of people and had put effort to know the reasons of spoilage. The deterioration is believed to cause mainly by the bacterial activity, which brings about very noticeable changes in the texture, flavour, odour and general appearance of the product. For this reason, we are concerned primarily with the deterioration of fish by microorganisms and microbial enzymes.

Mackerel fish (Scomberomorus guttatus, Bloch and Schneider) is a popular sea fish among the mackerel variety of fishes. It is found in around the Bay of Bengal and adjoining seas. In the Indian sub-continent it is called Surmai ${ }^{3}$. It is very cheap, tasty and easily available in the market, very popular and highly nutritious, used to make fish pickle and usually eaten as a condiment with rice, sought after food either cooked or as Sashimi, extremely high in vitamin $\mathrm{B}_{12}$, very high in omega 3 , very low in mercury and can be eaten twice a week according to EPA guidelines and in Scandinavia, canned mackerel in tomato sauce is commonly used as sandwich filling ${ }^{3}$.

Microorganisms differ in their responses to freezing, some survive virtually unharmed, some resist freezing but are susceptible to damage during frozen storage. Gram-negative organisms such as Escherichia, Pseudomonas, Alcaligenes, Vibrio and Salmonella are more sensitive to freezing than Gram-positive organisms ${ }^{4}$. The bacteria from skin and gills of fish and shellfish are predominantly aerobic. The population is inevitably facultative in nature. Matches et al. ${ }^{5}$ demonstrated that facultative anaerobic bacteria are predominating.

The spoilage of one fish has been demonstrated to cause mainly by bacterial activity. Spoilage bacteria grow almost entirely on the surface of fish. Some bacterial changes occur during spoilage

*Corresponding author:

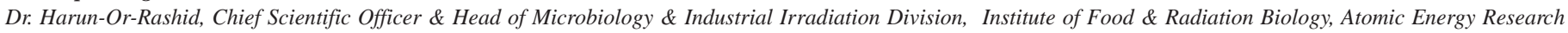
Establishment, Ganakbari, Savar, Dhaka 1000, Bangladesh

Tel (Office): (02) 7701228, (02) 7702033; Cell: 01552329012; Fax: +880 (02) 8613051: E-mail: hrashid15@hotmail.com 
of marine fish ${ }^{6}$. These are dependent not only on the strains of bacteria present, but also on the types of fish. Doyle ${ }^{7}$ reported that spoilage is the result of whole series of complicated deteriorative changes brought about by chemical action. The course of spoilage in any instance is subjected to the influence of environmental factors, particularly temperature ${ }^{8}$. The quality of fresh food like fish continuously changes during storage.

The use of low doses of radiation to destroy a sufficient number of microorganisms and enhance the storage life of goods is called radiation pasteurization ${ }^{9}$. Investigation on the fresh mackerel had shown the effectiveness of radiation for extending shelf life. John et al. ${ }^{10}$ observed that low dose of irradiation reduced bacterial growth. Radiation treatment can be a suitable method for mackerel fish preservation for further removal of associated microorganisms. Still there is no enough report regarding preservation of mackerel fish by radiation and low temperature. Therefore, the aim of this study was quantitative and qualitative microbiological analysis of economically important marine fish sample Scomberomorus guttatus (Atlantic mackerel) and the effect of frozen storage, gamma irradiation and combination treatment (frozen storage and gamma irradiation) on the associated microorganisms.

\section{Materials and Methods}

\section{Sample}

Atlantic mackerel (Scomberomorus guttatus) was used for the studying of the microbial spoilage of the fish. Combinations of different parts of the fish such as muscle, skin, fin etc. were used as materials for the study. The fish samples were collected from Savar market. The samples were thawed by keeping at room temperature and then they were cut into different pieces and kept into the pre-sterilized polythene bags. The investigation was carried in the laboratory of Microbiology and Industrial Irradiation Division (MIID), Institute of Food and Radiation Biology (IFRB), Atomic Energy Research Establishment (AERE), Savar, Dhaka.

\section{Microbiological analysis}

Total viable bacterial count (TVBC) was done by the standard plate count method following the method described by Sharp and Lyles ${ }^{11}$. Nutrient agar ( $\mathrm{pH}$ 7.0-7.4) was used to determine TVBC as well as for isolation purposes. Plates were incubated at $37^{\circ} \mathrm{C}$ for $24 \mathrm{~h}$ and the count was expressed as colony forming unit per gram (cfu/g). Total viable coliform count (TCC) was done in the same way using MacConkey agar medium at $37^{\circ} \mathrm{C}$. $\mathrm{mFC}$ agar medium and staphylococcal agar media were used for total faecal coliform count and total staphylococcal count respectively. With a view to identify some selected isolates various morphological characteristics, biochemical and carbohydrate fermentation tests were performed. All the bacterial isolates were identified according to the Bergey's Manual of Determinative Bacteriology ${ }^{12}$ and Manual for the Identification of Medical Bacteria ${ }^{13}$. Potato dextrose agar was used for total fungal count. The plates were incubated at $28^{\circ} \mathrm{C}$ and counts were recorded after 5 days of incubation. The fungal isolates were identified following the procedures described by Gilman ${ }^{14}$, Raper and Fennel ${ }^{15}$ and Koneman et al. ${ }^{16}$.

\section{Gamma irradiation}

The fish samples were subjected to different radiation doses such as 0 (control), 2.5, 57.5 and $10 \mathrm{kGy}$ of ionizing radiation at a dose rate of $1.25 \mathrm{Mrad} / \mathrm{h}$ from a 50,000 curie $\mathrm{Co}^{60}$ source (Gamma beam, 650, AECL, Canada) situated at the Institute of Food and Radiation Biology of AERE.

\section{Storage condition}

All of the untreated control and irradiated samples were stored in low temperature $\left(-20^{\circ} \mathrm{C}\right)$ in a deep freezer. The samples were then examined for microbiological qualities. Three replicas were studied for each of the sample. The bacteriological analyses were carried out before keeping the samples in the deep freeze and during storage once in a month up to six months.

\section{Results and Discussion}

The highest total viable bacterial count (TVBC) of the raw mackerel varied from $6.5 \times 10^{4}$ to $1.04 \times 10^{5} \mathrm{cfu} / \mathrm{g}$ (Table 1 ) and the average count of the five samples was $8.9 \times 10^{4} \mathrm{cfu} / \mathrm{g}$. The total coliform count (TCC) of the samples varied from $2.0 \times 10^{2}$ to $4.0 \times 10^{2} \mathrm{cfu} /$ $\mathrm{g}$ with an average $3.0 \times 10^{2} \mathrm{cfu} / \mathrm{g}$. Total faecal coliform count (TFCC) of the samples varied from nil to $2 \times 10^{2} \mathrm{cfu} / \mathrm{g}$ and the average count of the five samples was $6.0 \times 10^{1} \mathrm{cfu} / \mathrm{g}$. Total staphylococcal count (TSC) was also observed of the fish samples and the count varied from $3.8 \times 10^{4}$ to $4.4 \times 10^{4} \mathrm{cfu} / \mathrm{g}$ with an average count of $4.2 \times 10^{4} \mathrm{cfu} / \mathrm{g}$. There was no fungal count in any of the samples (Table 1). The similar bacteriological status of raw fish was observed previously by Rashid et al. ${ }^{17}$, Rahman et al. ${ }^{18}$ and Khatun et al. ${ }^{19}$.

Table 1. Quantitative assessment microorganisms in raw Atlantic mackerel fish

\begin{tabular}{lccccc}
\hline Sample & \multicolumn{5}{c}{ Count of viable microorganism (cfu/g) } \\
\cline { 2 - 6 } & TVBC & TCC & TFCC & TSC & TFC \\
\hline 1 & $1.04 \times 10^{5}$ & $3.0 \times 10^{2}$ & Nil & $4.4 \times 10^{4}$ & 0 \\
2 & $8.9 \times 10^{4}$ & $4.0 \times 10^{2}$ & $2.0 \times 10^{2}$ & $3.8 \times 10^{4}$ & 0 \\
3 & $6.5 \times 10^{4}$ & $3.0 \times 10^{2}$ & $1.0 \times 10^{2}$ & $4.0 \times 10^{4}$ & 0 \\
4 & $8.9 \times 10^{4}$ & $2.0 \times 10^{2}$ & 0 & $3.9 \times 10^{4}$ & 0 \\
5 & $9.8 \times 10^{4}$ & $3.0 \times 10^{2}$ & 0 & $3.9 \times 10^{4}$ & 0 \\
\hline
\end{tabular}

TVBC $=$ Total viable bacterial count; TCC $=$ Total coliform count; TFCC $=$ Total faecal coliform count; TSC = Total staphylococcal count (TSC); $\mathrm{TFC}=$ Total fungal count.

For observation of irradiation effect on microorganisms, five replicas of the samples were irradiated at $0,2.5,5.0,7.5$ and 10.0 kGy of irradiation doses and the residual microbial counts were analyzed. It was observed that in the non-irradiated samples the average of total viable bacterial count (TVBC) was $8.9 \times 10^{4} \mathrm{cfu} / \mathrm{g}$ and, after the irradiation, the count was decreased to $3.5 \times 10^{3} \mathrm{cfu} /$ 
$\mathrm{g}$ and nil at radiation doses of 2.5 and $5.0 \mathrm{kGy}$ respectively (Figure 1). Similar finding was also found in a previous study ${ }^{20}$ who reported that TVBC was reduced by two logs in all the samples at $2.5 \mathrm{kGy}$ of irradiation doses. Ito et al. ${ }^{21}$ also reported the same result. Total coliform count (TCC) was $3.0 \times 10^{2} \mathrm{cfu} / \mathrm{g}$ in the nonirradiated samples and after the irradiation at a dose of $2.5 \mathrm{kGy}$ the count was reduced to nil in all the samples. In case of total faecal coliform (TFC), the count in non-irradiated samples was $6.0 \times 10^{1}$ cfu/g and after the irradiation at a dose of $2.5 \mathrm{kGy}$ the count was decreased to nil. Irradiation effect was also observed in the total staphylococcal count (TSC). In the non-irradiated samples total staphylococcal count (TSC) was $4.0 \times 10^{4} \mathrm{cfu} / \mathrm{g}$ and the count was reduced to $3.0 \times 10^{2} \mathrm{cfu} / \mathrm{g}$ at a irradiation dose of $2.5 \mathrm{kGy}$. After the irradiation at a dose of $5.0 \mathrm{kGy}$, no count was observed. Similar results have been reported by Rashid ${ }^{20}$ and Ito et al. ${ }^{21}$.

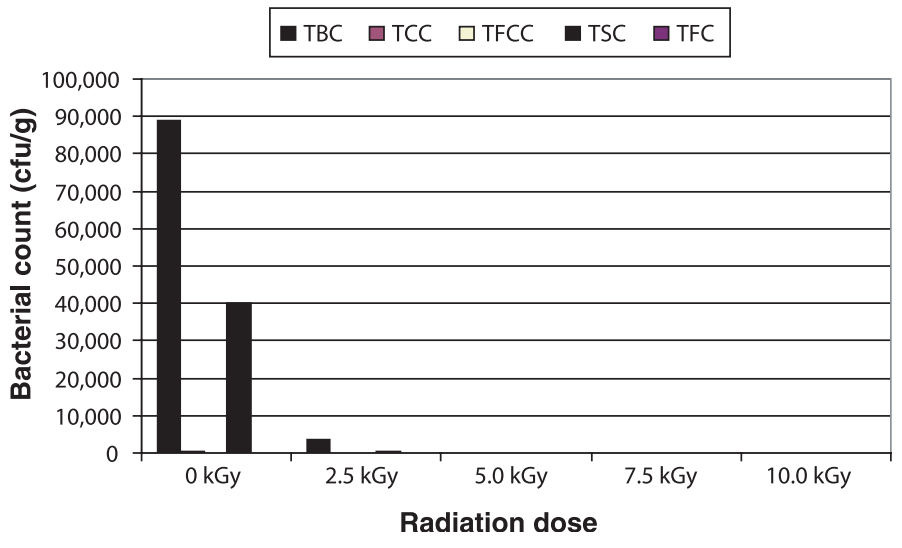

Figure 1. Effect of radiation on the survivability microorganisms associated with Atlantic mackerel fish. TVBC = Total viable bacterial count; TCC $=$ Total coliform count TFCC $=$ Total faecal coliform count; TSC = Total staphylococcal count (TSC); TFC $=$ Total fungal count .

The effect low temperature on the survivability of bacteria in fish was studied and the results are shown in Figure 2. After six month of storage the average of the total viable bacterial count (TVBC) reduced from an initial count of $8.9 \times 10^{4}$ to $5.7 \times 10^{3} \mathrm{cfu} / \mathrm{g}$. It was a common trend that the microbial count decreases gradually during storage at sub-freezing temperature. Like TVBC, total coliform count (TCC) and total faecal coliform count (TFCC) were also found to decrease gradually in all the samples during storage. No TFCC was found after storage for four months. The total staphylococcal count (TSC) was also decreased to about one log after six month of storage in all the samples. These results are in agreement with the results of several investigators ${ }^{22-25}$.

The declination in the rate of bacteria with time indicated their gradual adaptation to storage temperature. Slow freezing is more detrimental than quick freezing, because of the formation of large ice crystal that disrupts cell membranes as well as brings out solute of the cell ${ }^{26}$. Thus, freezing causes the death of the bacterial cell. Microorganisms differ in their responses to freezing ${ }^{27}$. Some

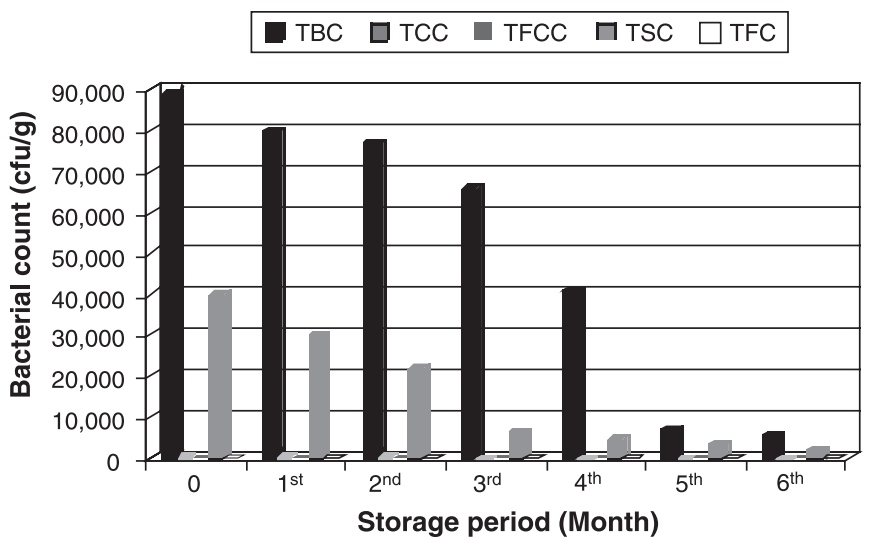

Figure 2. Effect of storage at low temperature $\left(-20^{\circ} \mathrm{C}\right)$ on the survivability microorganisms associated with Atlantic mackerel fish. TVBC = Total viable bacterial count; $T C C=$ Total coliform count TFCC = Total faecal coliform count; TSC = Total staphylococcal count (TSC); TFC = Total fungal count.

survive virtually unharmed, some resist freezing but are susceptible to damage during frozen storage or thawing, others are sensitive to freezing, storage and thawing and others are inactivated by freezing under nearly all conditions. Most spores and vegetative cells survive virtually unchanged. Most other non-spore forming organisms are sensitive to one or more steps of the freezing process ${ }^{27}$.

For observation of combination effect (irradiation and storage) on microorganisms the fish samples were irradiated at 0, 2.5, 5.0, 7.5 and $10.0 \mathrm{kGy}$ of irradiation doses and kept at $-20^{\circ} \mathrm{C}$ for six months. The microbial counts were observed monthly. It has been found that total viable bacteria were gradually decreased in all the samples and no count was observed after six months of storage in case of combination treatment. Total staphylococcal count was also gradually decreased and the count was nil after six months of storage. Total coliform and total faecal coliform bacteria were nil at the initial period of storage at the radiation level of $2.5 \mathrm{kGy}$, i.e., no count was observed during storage period of six months in the irradiated samples (Table 2). The bacteria survived after irradiation also gradually decreased during frozen storage and after six months of storage it was decreased about three to four log more in all the samples. Similar results have been reported by other investigators ${ }^{20,23,28}$.

On the basis of agar colony morphology different bacterial isolates were selected from different media for identification. A total of 64 isolates recovered from non-irradiated and irradiated fish samples were identified including Staphylococcus aureus, Micrococcus varians, Enterobacter cloacae, Klebsiella ozaenae, Bacillus subtilis, Escherichia coli, Bacillus megaterium, Klebsiella edwardsii, Pseudomonas aerugenosa and Micrococcus radiodurans. The bacteria isolated after six months of storage at $-20^{\circ} \mathrm{C}$ were S. aureus, M. varians, B. subtilis, E. coli, B. megaterium, K. edwardsii, P. aerugenosa and M. radiodurans. So, it was found that E. cloacae, K. ozaenae, B. subtilis and 
Table 2. Effect of combination treatments on the survivability microorganisms associated with Atlantic mackerel fish

\begin{tabular}{|c|c|c|c|c|c|}
\hline \multirow[t]{2}{*}{ Storage } & \multicolumn{5}{|c|}{ Count of viable microorganism (cfu/g) } \\
\hline & TVBC & TCC & TFCC & TSC & TFC \\
\hline \multicolumn{6}{|c|}{ Non-irradiated (Control) } \\
\hline Before storage & $8.9 \times 10^{4}$ & $3.0 \times 10^{2}$ & $6.0 \times 10^{1}$ & $4.0 \times 10^{4}$ & 0 \\
\hline After 1 month & $8.0 \times 10^{4}$ & $2.5 \times 10^{2}$ & $5.0 \times 10^{1}$ & $3.0 \times 10^{4}$ & 0 \\
\hline After 2 months & $7.7 \times 10^{4}$ & $2.0 \times 10^{2}$ & $3.0 \times 10^{1}$ & $2.2 \times 10^{4}$ & 0 \\
\hline After 3 months & $6.6 \times 10^{4}$ & $1.0 \times 10^{2}$ & $3.0 \times 10^{1}$ & $6.5 \times 10^{3}$ & 0 \\
\hline After 4 months & $4.1 \times 10^{4}$ & $1.0 \times 10^{1}$ & $1.5 \times 10^{1}$ & $4.5 \times 10^{3}$ & 0 \\
\hline After 5 months & $7.2 \times 10^{3}$ & $6.6 \times 10^{1}$ & 0 & $3.3 \times 10^{3}$ & 0 \\
\hline After 6 months & $5.7 \times 10^{3}$ & $3.0 \times 10^{1}$ & 0 & $2.0 \times 10^{3}$ & 0 \\
\hline \multicolumn{6}{|c|}{ Irradiated at $2.5 \mathrm{kGy}$} \\
\hline Before storage & $3.5 \times 10^{3}$ & 0 & 0 & $3.0 \times 10^{2}$ & 0 \\
\hline After 1 month & $3.0 \times 10^{3}$ & 0 & 0 & $2.5 \times 10^{2}$ & 0 \\
\hline After 2 months & $7.5 \times 10^{2}$ & 0 & 0 & $2.0 \times 10^{2}$ & 0 \\
\hline After 3 months & $4.5 \times 10^{2}$ & 0 & 0 & $1.0 \times 10^{2}$ & 0 \\
\hline After 4 months & $3.3 \times 10^{1}$ & 0 & 0 & 0 & 0 \\
\hline After 5 months & $2.5 \times 10^{1}$ & 0 & 0 & 0 & 0 \\
\hline After 6 months & 0 & 0 & 0 & 0 & 0 \\
\hline \multicolumn{6}{|c|}{ Irradiated at or above $5.0 \mathrm{kGy}$} \\
\hline Before storage & 0 & 0 & 0 & 0 & 0 \\
\hline After 1 month & 0 & 0 & 0 & 0 & 0 \\
\hline After 2 months & 0 & 0 & 0 & 0 & 0 \\
\hline After 3 months & 0 & 0 & 0 & 0 & 0 \\
\hline After 4 months & 0 & 0 & 0 & 0 & 0 \\
\hline After 5 months & 0 & 0 & 0 & 0 & 0 \\
\hline After 6 months & 0 & 0 & 0 & 0 & 0 \\
\hline
\end{tabular}

TVBC = Total viable bacterial count; TCC $=$ Total coliform count; TFCC $=$ Total faecal coliform count; TSC $=$ Total staphylococcal count $(\mathrm{TSC}) ; \mathrm{TFC}=$ Total fungal count .

M. radiodurans were eliminated after six months of storage. Among the 64 isolates 12 (19\%) were Staphylococcus, 7 (11\%) Micrococcus, 5 (8\%) Enterobacter, 11 (17\%) Klebsiella, 12 (19\%) Bacillus, 11 (17\%) Escherichia and 6 (9\%) Pseudomonas. Bacteria associated with stored fish muscle and their great variation in the percentage has been reported by Anwar et al. ${ }^{22}$.

It can be concluded that irradiation at frozen condition is useful to improve the keeping quality and lower the risk of food-borne illness caused by microorganisms.

\section{References}

1. Banks, H., R. Nickelson and A. Flene. 1980. Shelf-life studies on $\mathrm{CO}_{2}$ packaged, finfish from the Gulf of Maxico. J. Food Sci. 45: 157-162.

2. James MJ. 1986. Food preservation with chemicals. In Modern Food Microbiology, $3^{\text {rd }}$ edn, pp 259-280. Van Nostrand Reinhold, New York.

3. Anonymous. 2008. Atlantic mackerel. Available at: http:// en.wikipedia.org/wiki/Atlantic_mackerel. Accessed 10 October 2008.

4. Thomson WK \& Thacker CL. 1973. Effect of temperature on Vibrio parahaemolyticus in oysters at refrigerator and deep freeze temperatures. Can Inst Food Sci Technol J. 6: 156-158.

5. Matches JR, Liston J \& Curran D. 1974. Clostridium perfringens in the environment. Appl Microbiol. 28: 655-660.

6. Shewan JM. 1961. The microbiology of sea water fish. In Fish as Food (Bograstrom G ed), Vol I, pp 487-560. Academic Press, New York.

7. Doyle MP. 1985. Food borne pathogens of recent concern. Ann Rev Nuclr. 5: 25-41.
8. Reay GA \& Shewan JM. 1949. Spoilage of fish and its preservation by chilling. Adv Food Res. 2: 343-398.

9. Banwart J. 1979. Basic Food Microbiology, $2^{\text {nd }}$ edn, pp 218-225, 549-595, 601-603. CBS Publishers and Distributors, New Delhi.

10. John, A, Dassow J, David A \& Miyauchi T. 1965. Radiation preservation of fish and shell-fish of the north-east pacific and Gulf of Mexico. Radiation preservation of foods published National Academy of Science. National Research Council, Washington, DC.

11. Sharp MS \& Lyles ST. 1969. Laboratory Instructions in Biology of Microorganisms, pp 23-25. The CV Mosby Company, St. Louis.

12. Buchanan RE \& Gibbons NE. 1974. Bergey's Manual of Determinative Bacteriology, $8^{\text {th }}$ edn, pp 1268. The Williams \& Wilkins Co, Baltimore.

13. Cowan ST. 1975. Manual for the Identification of Medical Bacteria, $2^{\text {nd }}$ edn. Cambridge University Press, London.

14. Gilman JC. 1991. A Manual of Soil Fungi. The Iowa State University Press, Iowa.

15. Raper KB \& Fennell D. 1977. The Genus Aspergillus. Robert Krilger Publication Co, Huntington, New York.

16. Koneman EW, Robert GD \& Wright SF. 1978. Practical Laboratory Mycology, $2^{\text {nd }}$ edn, Williams and Wilkins Co, Baltimore.

17. Rashid H, Khan MR \& Chowdhury N. 1996. Microbiologycal aspects of frozen fish irradiation. Bangladesh J Microbiol. 13:(1-2): 83-88.

18. Rahman MM \& Chowdhury MR, Uddin MN \& Pal HK. 1998. Occurrence of ulcer disease in some wild fishes in Mymensing. Banladesh. Bangladesh J Microbiol. 15(2): 9-16.

19. Khatun M, Banu N, Hossain MM \& Hossain A. 1996. Stability of irradiation Kakila. Xenentodon cancila (Ham) at different storage temperature. Bangladesh J Zool. 24(2): 185-187. 
20. Rashid H. 2001. Studies on the microbiology of marine fish and their preservation by radiation and combination treatments. PhD Thesis. Department of Microbiology, University of Dhaka, Dhaka.

21. Ito H, Rashid HO, Sangthong N, Adulyatham P, Ratagool P \& Ishijaki I. 1993. Effect of gamma irradiation on frozen shrimp for decontamination of pathogenic bacteria. Radiat Phys Chem. 42(1-3): 279-282.

22. Anwar MN, Shah SB \& Hakim MA. 1998. Effect of freezing and frozen storage on the quantity and types of bacteria in shrimp. Bangladesh J Bot. 17(1): 85-88.

23. Anwar MN, Shah SB \& Khan MSA. 1988. Effect to freezing and frozen storage on the faecal indicator organisms in shrimp. Bangladesh J Bot. 17(1): 95-97.
24. Haines RB. 1938. The effect of freezing on bacteria. Proc $R$ Soc $B r$. 124: 451-463.

25. Hobbs BC. 1976. Microbiological hazards of international trade. In Microbiology in Agriculture, Fisheries and Food (Skinner FA \& Carr JG eds), pp 161-180. Academic Press, New York.

26. Fung DYC. 1987. Types of microorganisms. In The Microbiology of Poultry Meat Products (Cunningham FE \& Cox FE eds), p 21. Academic Press Inc, Florida.

27. Fennema OR, Powrie WD \& Marth EH. 1973. Low Temperature Preservation of Foods and Living Matter. Marcel Dekker, New York.

28. Thampuran N \& Gopakurmar K. 1991. Microbial profile of tropical prawn (Metapenaeus dobsoni) during frozen storage. J Food Sci Technol India. 28(6): 371-374. 